\title{
Sustainable Entrepreneurship: Innovation-Related Activities in European Enterprises
}

\author{
Maria Urbaniec* \\ Cracow University of Economics, Faculty of Economics and International Relations, \\ Department of Entrepreneurship and Innovation, Kraków, Poland
}

Received: 4 September 2017

Accepted: 1 October 2017

\begin{abstract}
The primary basis of the term sustainable entrepreneurship is the concept of sustainable development. Sustainable development aims at the protection of nature, life support, and community in the pursuit of perceived opportunities to bring into existence future products and processes with both economic and non-economic gains to individuals, the economy, and society. The growing importance of environmental issues and sustainable development have given rise to the concept of sustainable entrepreneurship. Sustainable entrepreneurship can be considered an opportunity for business development practices at the nexus of environmental and social aspects. Companies increasingly consolidate their competitive position through innovative actions in the field of sustainability. The aim of this article is to analyze the role of innovation-related activities in European businesses based on the concept of sustainable entrepreneurship. On this basis, it can be stated that sustainable entrepreneurship provides new opportunities for the development of corporate responsibility, taking into account ecological and social issues.
\end{abstract}

Keywords: sustainable entrepreneurship, sustainability, sustainable technologies, innovation activities, Eurobarometer

\section{Introduction}

As a result of global challenges, taking action on economic development consistent with the principles of sustainable development is an important task for governments, academia, and industry around the world. The growing importance of environmental issues and sustainable development have given rise to the concept of sustainable entrepreneurship. Sustainable entrepreneurship aims at the protection of nature, life support, and community in the pursuit of perceived

*e-mail: maria.urbaniec@uek.krakow.pl opportunities to bring into existence future products and processes with both economic as well as non-economic gains to individuals, the economy, and society [1]. The importance of sustainable entrepreneurship can be considered as a unique perspective that links the creation of economic, social, and environmental values with a focus on the well-being of future generations [2-3]. Companies taking into account environmental and social aspects are considered to be innovative. A common feature of such entrepreneurs is that their goal is not only to achieve profitability by meeting specific needs, but also to achieve a positive impact on society and the environment. This may be reflected in the saving of raw materials (e.g., packaging) or electricity (e.g., bioenergy), 
or consolidating existing ecosystems (e.g., honey from neighbouring areas). Sustainable entrepreneurship is perceived as a solution to, rather than a cause of, environmental degradation and social inequality.

Furthermore, the role of social and ecological problems as potential sources of entrepreneurial opportunities is largely unexplored in literature. Sustainable entrepreneurship continues to be perceived as a new field of research and needs to explore the mechanisms for sustaining nature and ecosystems while providing economic and social gains for investors, entrepreneurs, and societies. It can be examined from the point of view of different disciplines of social sciences (economics, law, organizational theory, political science, psychology, sociology, strategic management etc.) as well as different methodological approaches that can be used for that purpose (e.g., case study, simulation, statistical analysis, development theory).

The aim of this article is to analyze the role of innovation-related activities in European businesses based on the concept of sustainable entrepreneurship. This will allow us to answer the question of what are the benefits to companies engaging in sustainable entrepreneurship. For this purpose, the essence and importance of sustainable entrepreneurship will be presented, followed by the innovation-related activities to sustainable development exemplified by European firms. The research was carried out based on the method of literature analysis and critique as well as qualitative and quantitative secondary data using documents and the available results of surveys conducted for the European Commission.

\section{Literature Review}

Sustainable entrepreneurship is a new concept that links sustainable development to business activities [4]. The term "sustainable entrepreneurship" is based on the concept of sustainable development, which is defined as "development that meets the needs of the present without comprising the ability of future generations to meet their own needs" [5, p. 43]. This definition implies the principles of intragenerational equity (present generations) and intergenerational equity (future generations), which are also within the focus of sustainable entrepreneurship [6]. Sustainable entrepreneurship is addressed to the social aspects (attention is given to stakeholders, such as community, partners, workers, etc.), environmental aspects (referring to long-term protection and the reduction of negative effects), and economic aspects (focus on economic growth while keeping in mind the previous two dimensions).

In the literature, there are various definitions of sustainable entrepreneurship, which can generally be described from two perspectives. On the one hand, publications in sustainable management journals refer to the concepts of sustainable development and the triple bottom line, while entrepreneurial activities remain subordinate to these. On the other hand, publications in mainstream entrepreneurship journals adjust the notion of the triple bottom line with the process perspective of entrepreneurship. According to Belz and Binder [7], the triple bottom line of ecological, social, and economic aspects of sustainable entrepreneurship is integrated successively, not simultaneously. Based on a convergent process model of sustainable entrepreneurship, they show that successive order in the development process reduces the complexity of the challenging task, and renders the integration and balancing process easier and more manageable for the co-founders [7]. Schaltegger and Wagner [4] indicate that sustainable entrepreneurship aims at balancing the triple bottom line of economic, social, and ecological goals, which are at times mutually reinforcing, but there are often trade-offs, emphasizing the ambiguities, contradictions and complexities of sustainable entrepreneurship. Cohen and Winn [8] define sustainable entrepreneurship as an analysis of the exploration of opportunities. This is due to the fact of how and by whom future goods and services are discovered, developed and used, as well as with what economic, psychological, social, and environmental consequences. They also highlight that "the addition of environmental consequences offers an expanded and significantly modified definition for the field of entrepreneurship" [8, p. 35].

In this context, new terms have emerged, such as green entrepreneurship, environmental entrepreneurship, or ecopreneuring, as well as social entrepreneurship [911]. While social entrepreneurship usually considers the double bottom line of social and economic value [1215], ecopreneurship refers to ecological and economic goals $[4,16]$. Despite some similarities between green entrepreneurship, social entrepreneurship, and sustainable entrepreneurship, there are also some differences between the two concepts regarding (1) the multiplicity of goals, (2) the notion of equity, and (3) the type of organization involved [7].

Although sustainable entrepreneurship has many features in common with environmental and social entrepreneurship, the coherent pursuit of economic viability, social equity, and environmental stability distinguishes sustainable entrepreneurship from other concepts [6]. The following Table outlines some definitions of sustainable entrepreneurship with the aim of identifying differences and similarities, as well as to determine which aspects are important according to the researcher. These definitions are ranked by the year of publication (keeping in line with the chronological approach).

The definitions presented in Table 1 provide valuable insight into the development of sustainable entrepreneurship, enabling an overview identifying the various attributes and key traits that have developed over the years. One can note that sustainable entrepreneurship definitions encompass three attributes: 1) balancing environmental and social concerns with economic gains (action orientation), 2) creating new value and innovation 
Table 1. Definitions of sustainable entrepreneurship.

\begin{tabular}{|c|c|c|}
\hline Authors (year) & Definition & Research orientation \\
\hline $\begin{array}{c}\text { Crals and } \\
\text { Vereeck [17] }\end{array}$ & $\begin{array}{l}\text { "The continuing commitment by businesses to behave ethically and con- } \\
\text { tribute to economic development while improving the quality of life of the } \\
\text { workforce, their families, the local and global community as well as future } \\
\text { generations." }\end{array}$ & $\begin{array}{c}\text { Why? / What? } \\
\text { (action and effect orientation) }\end{array}$ \\
\hline $\begin{array}{c}\text { Dean and } \\
\text { McMullen [18] }\end{array}$ & $\begin{array}{c}\text { "The process of discovering, evaluating, and exploiting economic opportu- } \\
\text { nities that are present in market failures which detract from sustainability, } \\
\text { including those that are environmentally relevant." }\end{array}$ & $\begin{array}{c}\text { How? } \\
\text { (process orientation) }\end{array}$ \\
\hline $\begin{array}{c}\text { Cohen and Winn } \\
{[8]}\end{array}$ & $\begin{array}{l}\text { "The examination of how opportunities to bring into existence 'future' goods } \\
\text { and services are discovered, created, and exploited, by whom, and with what } \\
\text { economic, psychological, social, and environmental consequences." }\end{array}$ & $\begin{array}{c}\text { How? / What? } \\
\text { (process and effect orientation) }\end{array}$ \\
\hline $\begin{array}{c}\text { Hockerts and } \\
\text { Wüstenhagen [3] }\end{array}$ & $\begin{array}{l}\text { "The discovery and exploitation of economic opportunities through the } \\
\text { generation of market disequilibria that initiate the transformation of a sector } \\
\text { towards an environmentally and socially more sustainable state." }\end{array}$ & $\begin{array}{l}\text { How? / Why? } \\
\text { process and action orientation }\end{array}$ \\
\hline $\begin{array}{l}\text { Schaltegger and } \\
\text { Wagner [4] }\end{array}$ & $\begin{array}{l}\text { "An innovative, market-oriented and personality driven form of creating } \\
\text { economic and societal value by means of break-through environmentally or } \\
\text { socially beneficial market or institutional innovations." }\end{array}$ & $\begin{array}{l}\text { How? } \\
\text { process orientation }\end{array}$ \\
\hline $\begin{array}{l}\text { Shepherd and } \\
\text { Patzelt [1] }\end{array}$ & $\begin{array}{l}\text { "Is focused on the preservation of nature, life support, and community in the } \\
\text { pursuit of perceived opportunities to bring into existence future products, } \\
\text { processes, and services for gain, where gain is broadly construed to include } \\
\text { economic and non-economic gains to individuals, the economy, and society." }\end{array}$ & $\begin{array}{l}\text { What? / Why? } \\
\text { effect and action orientation }\end{array}$ \\
\hline $\begin{array}{l}\text { Patzelt and } \\
\text { Shepherd [19] }\end{array}$ & $\begin{array}{l}\text { "The discovery, creation, and exploitation of opportunities to create future } \\
\text { goods and services that sustain the natural and/or communal environment and } \\
\text { provide development gain for others." }\end{array}$ & $\begin{array}{l}\text { How? } \\
\text { process orientation }\end{array}$ \\
\hline $\begin{array}{l}\text { Belz and Binder } \\
\text { [7] }\end{array}$ & $\begin{array}{l}\text { "Sustainable entrepreneurship as the recognition, development and exploita- } \\
\text { tion of opportunities by individuals to bring into existence future goods and } \\
\text { services with economic, social and ecological gains." }\end{array}$ & $\begin{array}{l}\text { How? / What? } \\
\text { process and action orientation }\end{array}$ \\
\hline
\end{tabular}

Source: Own study

(process orientations), and 3) transforming companies, sectors, or economies toward sustainability (effect orientation). Considering the purpose of this article, all three attributes are an important issue in the context of the current opportunities and challenges associated with the implementation of sustainable entrepreneurship. However, due to the limited volume of the article, a special attention will be paid to the effects resulting from the transformation of enterprises toward sustainability.

The definition and core assumption of sustainable entrepreneurship are still evolving since this field of research is not yet fully developed [1, 20-21]. Due to the variety of definitions, it should be emphasized that both the measurement of the actions implemented as well as an assessment of the results achieved is therefore significantly impeded. Thus, sustainable entrepreneurship can be defined as a type of business development practice that provides new opportunities for innovative corporate activities at the nexus of ecological and social issues.

\section{Material and Methods}

To analyze the benefits related to sustainable business development, secondary data from a survey conducted under "Innobarometer 2016: EU business innovation trends" [22] were used. This survey was carried out for the European Commission by the TNS Political \& Social network in the EU 28 member states as well as Switzerland and the USA in February 2016 based on interviews conducted among 14,117 enterprises (13,117 of which were from the EU 28 member states, and 500 each from Switzerland and the United States). The sample included companies employing one or more persons in manufacturing, services, and the industry sector. The sample was selected from an international database, with an additional sample from local sources where necessary [22]. The interviews were conducted with key decision makers of companies by telephone in their native language on behalf of the European Commission (DG internal market, industry, entrepreneurship, and SMEs). The methodology applied is based on that of Eurobarometer surveys.

The analysis relied on secondary data, which are often used in research. The use of secondary data analysis to identify the role of a sustainable entrepreneurship in European companies is an appropriate approach for many reasons.

- First, these data include extensive test research, taking into account a large number of enterprises in different countries (more than 14,000 firms) and from various industries. 
- Second, secondary data allows us to describe reality, to verify previously accumulated knowledge, and select indicators and inference based on professionally conducted and publicly available data that support generalizations.

- Third, the collection and analysis of secondary data tends to be less time-consuming and less expensive than the collection of data from primary sources.

- Fourth, the existing data allow for re-examination in the same conditions and according to a fixed scheme, and thus create the possibility of replication.

- Fifth, the secondary data provide high quality results through the possibility of eliminating questionable and incomplete materials and reduce the risk of participating in the study by people with limited knowledge and competence [23].

Despite many advantages, it is often pointed out that the results derived from secondary data analysis have limitations, namely that information is too general and can rarely be directly applied to address specific problems [24-25].

However, it should be emphasized that the use of methods of secondary data analysis in this article is reasonable because it allows us to identify the development of European companies in the field of sustainable entrepreneurship. The key advantage of using secondary data is the fact that they increase the sample size, the representativeness, and the number of observations - all of which lead to broader applications. On this basis, an attempt will be taken to find an answer to the question of what are the benefits to companies that undertake activities toward sustainable development.

\section{Results and Discussion}

When evaluating the innovativeness of enterprises as a basic condition toward sustainable development, it should be stated that, according to a study within the framework of [22], more than two-thirds of companies in the EU have introduced at least one innovation from January 2013 (67\%). This reflects a decrease of five percentage points as compared to the survey in 2015 (72\%), and an increase of one percentage point compared to $2014(66 \%)$. Four in 10 EU companies have introduced new or significantly improved products $(40 \%)$ or new or significantly improved services (40\%). More than $30 \%$ of EU companies implemented new or significantly improved organizational methods (34\%), new or significantly improved marketing strategies (33\%), or new or significantly improved processes $(30 \%)$. For most companies, innovative products and services account for $1-25 \%$ of their turnover $(62 \%)$, and another $17 \%$ indicated that they represent more than $26 \%$ of their turnover [22].

This level of enterprise innovativeness can be considered as a sufficient basis for implementing sustainable-oriented activities. It means that innovations can have a significant impact on the transformation of an industry toward sustainability. Analyzing the role of technology, it can be stated that companies apply sustainable technologies to a relatively low extent. Only $16 \%$ of companies used sustainable manufacturing technologies, $17 \%$ of companies prefer high-performance manufacturing technologies, and $11 \%$ IT-enabled intelligent manufacturing technologies. However, most companies did not use any of these types of technologies $(66 \%)$. On the one hand, this may be due to the lack of benefits or incentives to use sustainable technologies, and on the other, the support of enterprises in the implementation of these types of technologies is needed.

Given the plans for using such technologies in the near future, no clear improvement can be seen either. Less than one in 5 companies over the next 12 months plans to apply high-performance manufacturing technologies $(19 \%)$, sustainable manufacturing technologies (15\%), or IT-enabled intelligent manufacturing technologies (10\%). In contrast, almost two-thirds of companies do not plan to use any of the specified technology (64\%) (Table 2), which means a significant increase of 12 percentage points compared to the survey conducted in 2015 [26].

Table 2. Types of advanced manufacturing technologies used and planned for use in the EU in 2016 (in \%).

\begin{tabular}{|c|c|c|}
\hline Types of manufacturing technologies & $\begin{array}{c}\text { Have you used any } \\
\text { of the following } \\
\text { technologies? }\end{array}$ & $\begin{array}{c}\text { Do you plan to use any } \\
\text { of the following technologies } \\
\text { in the next } 12 \text { months? }\end{array}$ \\
\hline $\begin{array}{c}\text { High-performance manufacturing that combines flexibility, precision, } \\
\text { and zero defects (e.g., high-precision machine tools, advanced sensors, } \\
\text { or 3D printers) }\end{array}$ & 17 & 19 \\
\hline $\begin{array}{c}\text { Sustainable manufacturing technologies (i.e., technologies that use en- } \\
\text { ergy and materials more efficiently and drastically reduce emissions) }\end{array}$ & 16 & 15 \\
\hline $\begin{array}{c}\text { IT-enabled intelligent manufacturing (i.e., technologies that digitize } \\
\text { production processes) }\end{array}$ & 11 & 64 \\
\hline None & 66 & 4 \\
\hline Don't know & 2 & 64 \\
\hline
\end{tabular}

Base: All manufacturing companies $(\mathrm{n}=1151), 9 \%$ of base

Source: Own compilation based on European Union [22, p. 100, 102]. 


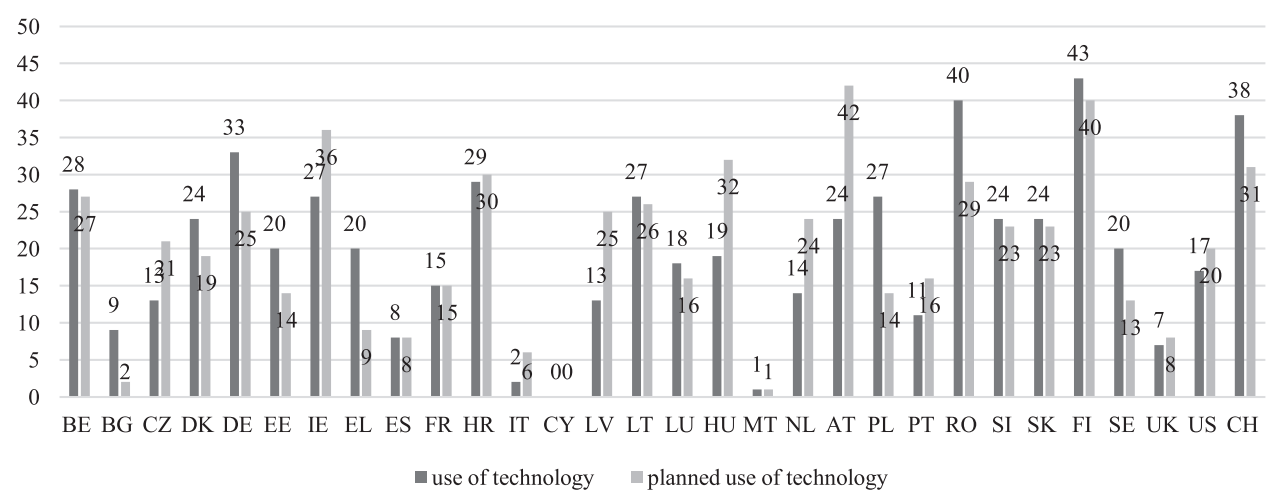

Fig. 1. The use of sustainable manufacturing technologies in 2016 and their planned use over the next 12 months. Source: Own compilation based on European Union [22, p. T62, T65].

In line with this study, most companies do not apply and have no plans to apply technologies that support sustainable development and limit detrimental effects on the environment and society. This indicates a weak involvement in the field of sustainable entrepreneurship and thereby slows down the transition toward a sustainability-oriented economy.

Analyzing the use of sustainable manufacturing technologies across the EU, it can be stated that companies from Finland (43\%), Romania (40\%), Switzerland (38\%), and Germany (33\%) are most active. However, in the next 12 months the application of such technologies is planned by companies in Austria (42\%), Finland (40\%), Ireland (36\%), Hungary (32\%), Switzerland (31\%), and Croatia (30\%) (Fig. 1).

Regarding areas in which companies can undertake innovation activities, different social, environmental, and economic benefits are possible. Companies usually indicate social benefits, such as the creation of new jobs $(19 \%)$, lifelong learning and skills development (15\%), while health and medical care are only $5 \%$. Given the environmental benefits, this study revealed that environmental protection (11\%) and resource efficiency $10 \%$ ) may have a positive impact on innovation activities. This means that approximately one company in 10 will be engaged in environmental innovations. Concerning economic benefits, companies demonstrate a positive impact mainly on IT and the digital economy (14\%). Less than $10 \%$ of companies believe that innovation implemented over the next 5 years will have a positive impact on transport and transport infrastructure (9\%), construction solutions for future smart cities $(8 \%)$, the availability and quality of food $(6 \%)$, or even space applications (1\%) (Fig. 2).

Furthermore, given the size of the companies, it can be stated that larger enterprises with 250 or more employees indicate more often a positive impact than smaller companies with 1-9 employees. The innovations implemented in their companies have a positive impact on resource efficiency ( $24 \%$ of large companies and $9 \%$ of micro), IT and the digital economy ( $23 \%$ of large companies and $14 \%$ of micro), transport and transport infrastructure ( $22 \%$ of large companies and $8 \%$ of micro), and environmental protection (17\% of large companies

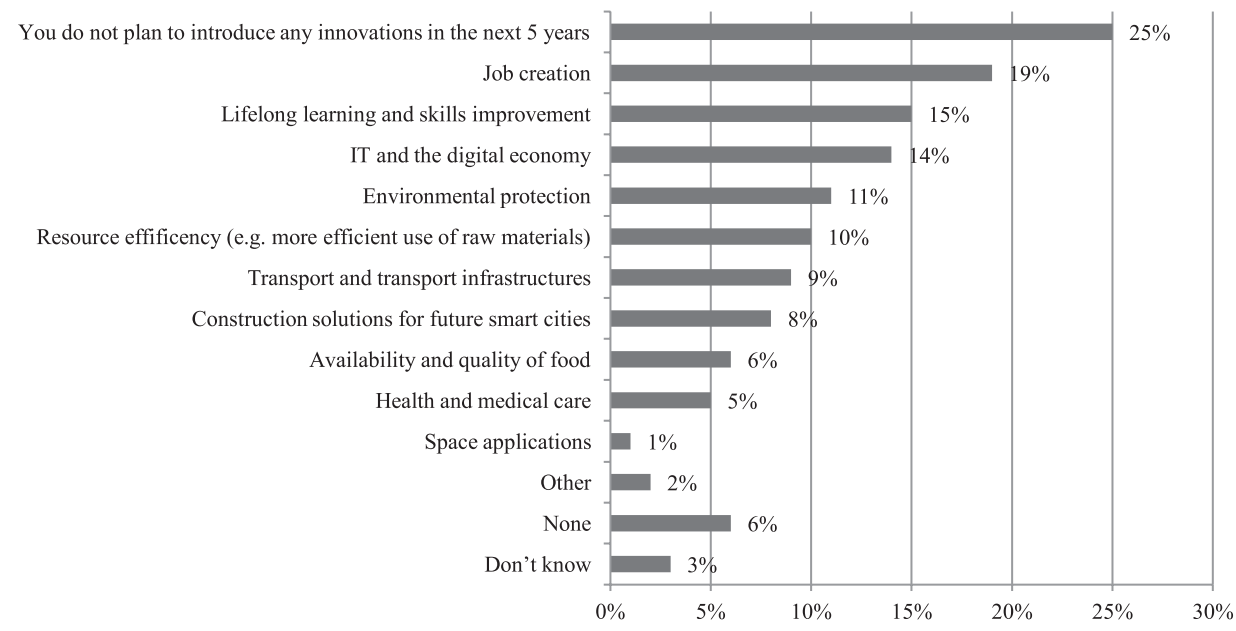

Fig. 2. Areas having a positive impact on innovation activities over the next 5 years.

Database 2016: all production companies ( $\mathrm{n}=13,112$, i.e. $100 \%$ of the entire company base)

Source: Own compilation based on European Union [22, p. 24]. 
and $11 \%$ of micro). Regarding the type of sector, service companies demonstrate more often than other sectors that their innovation activities will have a positive impact on IT and the digital economy (20\% of large companies and $7-12 \%$ of micro). In the case of the industrial sector, companies indicate that the innovation activities will have a positive impact on the environment $(20 \%$ of large companies and $10 \%$ of micro) [22].

Summing up, a relatively high percentage of innovative companies in the European Union (72\%) may constitute the potential to implement the concept of sustainable entrepreneurship. However, given the results relating to currently used and planned manufacturing technologies, the situation is not satisfactory. Companies implement sustainable technologies to a relative low extent (only 16\%). Considering the assumptions of sustainable development, the conducted research can be seen as an attempt to analyze and evaluate the benefits of innovation activities of companies. These benefits may relate not only to economic areas, but also to social and environmental issues.

The dynamic and uncertain economic environment and business reality requires from companies new ways to achieve their strategic objectives and ensure their longterm success. Many strive to create new opportunities, thus gaining a better market position and creating a competitive advantage over their competitors [27]. However, companies operating in the field of sustainable development must overcome many dilemmas $[8,20]$. On the one hand they want to invest their profits directly into their social and ecological core business without taking into account the appropriate budget for marketing and running a business. On the other hand they must consolidate their position in the same economy and win over customers and public opinion. It can be assumed that entrepreneurs introducing sustainable products, processes, and services will be able to create profitable enterprises while achieving specific environmental and/ or social objectives in order to change nature, sources of life support, and communities. The green and socialoriented entrepreneurial business model should take into account the specific nature of the sector from the point of view of innovation.

\section{Conclusions}

The research analysis in this article can be considered as an attempt to find an answer to the questions of what is the role of innovation-related activities in European businesses based on the concept of sustainable entrepreneurship as well as what are the benefits to companies engaging in sustainable entrepreneurship? Research shows that there are different dependences between innovative enterprise development and sustainable entrepreneurship. The positive issue is the relatively good innovativeness of European companies, which provides substantial potential for the implementation of innovation activities related to sustainable entrepreneurship. Constant technological improvements and innovation can be considered as an assistance to the progress of sustainable entrepreneurship. By contrast, the challenge is a rather weak commitment to sustainable development, and failure of the enterprises to recognize benefits from the implementation of sustainable technologies. In order to succeed in creating a sustainable business and competing in the market, it is vital to foster sustainability oriented benefits. The social and ecological areas may be a potential source of new entrepreneurial opportunities.

This paper makes three contributions to the field of sustainable entrepreneurship. Firstly, it reviews existing definitions of sustainable entrepreneurship and conceptualises a new one. Thus, sustainable entrepreneurship can be defined as the types of business development practices that provide new opportunities for innovative corporate activities at the nexus of ecological and social issues. The analysis of different definitions of sustainable entrepreneurship provide valuable insight into the development of this concept, enabling an overview identifying the various attributes that have developed over the years. One can note that sustainable entrepreneurship definitions encompass three attributes that are focused on action, process, and effects.

Secondly, it explores the innovation-oriented activities supporting sustainable entrepreneurship in European companies. Companies demonstrate a positive impact on social, environmental, and economic benefits, e.g., the creation of new jobs and lifelong learning and skills development, promotion of IT and the digital economy, environmental protection, and resource efficiency. Based on the assumption that innovation is one of the key feature of sustainable entrepreneurship, it can be concluded that innovation activities play an important role in the transition toward sustainability in companies.

Finally, the analysis enhances the theoretical understanding of how innovation-oriented activities can help solve environmental and social problems by indicating potential benefits to European companies. This study contributes to the literature on sustainable entrepreneurship by highlighting the meaningful role played by innovations in improving environmental and social performance.

Sustainable development is a complex model that cannot be assigned to a single discipline [20]. Due to social and environmental challenges in the global context, the close cooperation of different disciplines is required, which allows for exceeding the traditional boundaries of these disciplines. Interdisciplinarity in sustainable development research means that the methodology of economics should employ a variety of disciplines and basic methods aimed at describing and explaining scientific facts [19, 28-29]. Therefore, it is important to continue exploration in order to understand and minimize the negative effects associated with social and environmental issues. Activities conducive to sustainable development should be undertaken with 
regard to the concept of sustainable entrepreneurship. Hence, there is the need for reinforcing sustainability in European businesses because the relatively high level of innovation does not reflect the engagement of enterprises toward sustainable entrepreneurship.

\section{Acknowledgements}

This article came into being within statutory research project No. 067/WE-KPI/01/2017/S/7067 entitled "Entrepreneurship in an international perspective," financed by the Ministry of Science and Higher Education of the Republic of Poland with the funds allocated to development of research potential of the Faculty of Economics and International Relations of Cracow University of Economics.

\section{References}

1. SHEPHERD D.A., PATZELT H. The New Field of Sustainable Entrepreneurship: Studying Entrepreneurial Action Linking 'What Is to Be Sustained' With 'What Is to Be Developed. Entrepreneurship: Theory and Practice 35 (1), 137, 2011.

2. ANDERSON A.R. Cultivating the Garden of Eden: environmental entrepreneuring. Journal of Organizational Change Management 11 (2), 135, 1998.

3. HOCKERTS K., WÜSTENHAGEN R. Greening Goliaths versus emerging Davids - Theorizing about the role of incumbents and new entrants in sustainable entrepreneurship. Journal of Business Venturing 25 (5), 481, 2010.

4. SCHALTEGGER S., WAGNER M. Sustainable entrepreneurship and sustainability innovation: categories and interactions. Business Strategy and the Environment 20 (4), 222, 2011.

5. WCED (World Commission on Environment and Development) Our Common Future, Oxford: Oxford University Press, 1987.

6. THOMPSON N., KIEFER K., YORK J.G. Distinctions not dichotomies: exploring social, sustainable, and environmental entrepreneurship. Advances in Entrepreneurship, Firm Emergence and Growth Vol. 13, 205, 2011.

7. BELZ F.M., BINDER J.K. Sustainable Entrepreneurship: A Convergent Process Model", Business Strategy and the Environment 26, 1, 2017.

8. COHEN B., WINN M.I. Market imperfections, opportunity and Sustainable Entrepreneurship. Journal of Business Venturing 22 (1), 29, 2007.

9. SCHALTEGGER S. A framework for ecopreneurship: Leading bioneers and environmental managers to ecopreneurship. Greener Management International 38 (38), 45, 2002.

10. PACHECO D.F., DEAN T.J., PAYNE D.S. Escaping the green prison: Entrepreneurship and the creation of opportunities for sustainable development. Journal of Business Venturing 25 (5), 464, 2010.

11. SKOPENKO N., SAGAYDACK J. Specific Features of Development of Ecological Entrepreneurship in Ukraine. Economics \& Sociology 6 (2), 28, 2013.
12. SHORT J., MOSS T., LUMPKIN G. Research in social entrepreneurship: past contributions and future opportunities. Strategic Entrepreneurship Journal 3 (2), $161,2009$.

13. DACIN P.A., DACIN M.T., MATEAR M. Social entrepreneurship: why we don't need a new theory and how we move forward from here. The Academy of Management Perspectives 24 (3), 37, 2010.

14. ŻUR A. Social problems as sources of opportunity antecedents of social entrepreneurship opportunities. Entrepreneurial Business and Economics Review 3 (4), 73, 2015.

15. GREBLIKAITE J., SROKA W., GERULAITIENE N. "Involving Young People in Polish and Lithuanian Social Enterprises by Fostering Entrepreneurial Skills and Abilities as Entrepreneurial Opportunity at University. Entrepreneurial Business and Economics Review 4 (3), 131, 2016.

16. LARSON A.L. Sustainable innovation through an entrepreneurship lens. Business Strategy and the Environment 9 (5), 304, 2000.

17. CRALS E., VEREECK L. The affordability of sustainable entrepreneurship certification for SMEs. International Journal of Sustainable Development \& World Ecology 12, 173, 2005.

18. DEAN T.J., MCMULLEN J.S. Toward a theory of Sustainable Entrepreneurship: Reducing environmental degradation through entrepreneurial action. Journal of Business Venturing 22, 50, 2007.

19. PATZELT H., SHEPHERDD.A. Recognizing Opportunities for Sustainable Development. Entrepreneurship: Theory and Practice 35, 631, 2011.

20. SPAISER V., RANGANATHAN S., SWAIN R.B., SUMPTER D.J.T. The sustainable development oxymoron: quantifying and modelling the incompatibility of sustainable development goals. International Journal of Sustainable Development \& World Ecology, 2016, DOI: 10.1080/13504509.2016.1235624

21. YORK J.G., VENKATARAMAN S. The entrepreneurenvironment nexus: Uncertainty, innovation, and allocation, Journal of Business Venturing 25 (5), 449, 2010.

22. EUROPEAN UNION. Innobarometer 2016 - EU business innovation trends. Report, Flash Eurobarometer 433 - TNS Political \& Social, Brussels, 2016.

23. JOHNSTON M.P. Secondary Data Analysis: A Method of which the Time Has Come. Qualitative and Quantitative Methods in Libraries (QQML) 3, 619, 2014.

24. VARTANIAN T.P. Secondary data analysis, New York, NY: Oxford, 2011.

25. DALE A., ARBOR S., PROCTER M. Doing secondary analysis, London: Unwin Hyman, 1988.

26. EUROPEAN UNION. Innobarometer 2015-The innovation trends at EU enterprises. Report, Flash Eurobarometer 415 - TNS Political \& Social, Brussels, 2015.

27. URBANIEC M. Towards Sustainable Development trough Eco-innovations: Drivers and Barriers in Poland. Economics \& Sociology 8 (4), 179, 2015.

28. HARBI, S. E., ANDERSON, A. R., AMMAR, S. H. Entrepreneurs and the environment: towards a typology of Tunisian ecopreneurs. International Journal of Entrepreneurship and Small Business 10 (2), 181, 2010.

29. URBANIEC M. Measuring and Monitoring Effects of Sustainable Development in the European Union. European Journal of Sustainable Development 5 (1), 1, 2016. 
